\title{
CARRIAZO (1899-1989)
}

\author{
por RAFAEL COMEZ
}

La excepcional erudición de Don Juan de Mata Carriazo y Arroquia quedaba sólo contrastada por su extraordinaria elocuencia. Tuve la suerte de ser su alumno en uno de los últimos años de su vida docente. Era capaz de proporcionar en magistral y amena síntesis un cuadro de la vida en cualquier momento de la Prehistoria sin que decayera la atención de la clase. Muchos de los datos históricos que revelaba eran tan vívidos como hallazgos propios atesorados a través de su larga vida de arqueólogo. ¿Podemos negar que las puntas de flecha de cristal de roca del dolmen de Ontiveros, sean - como él afirmaba con emoción - las más bellas de la Prehistoria?

El descubrimiento del tesoro del Carambolo supuso un hito indiscutible en el desarrollo de los estudios de la España antigua, que ya contaba con la aportación del famoso «bronce Carriazo».

Nadie que no supiera redactar podría superar fácilmente los exámenes de Don Juan de Mata. Pero también aconsejaba la lectura de Azorín a aquellos cuya prosa constituía períodos tan largos que se hacían ininteligibles. Asimismo, con suprema elegancia y discreta ironía, invitaba a abandonar el aula a la colegiala esquirola que se empecinaba en asistir a clase durante la huelga del 68.

Su conocimiento de las crónicas medievales le permitía aquel despliegue erudito, pletórico de sabrosas observaciones y atinadas enseñanzas. Su estilo, muy didáctico, pleno de imágenes, era peculiar de quien ha tenido un continuo trato con las formas artísticas. Su estudio de la campaña de Granada por los Reyes Católicos, a través de los relieves de la sillería de coro de la catedral de Toledo nos revela su interés por la iconografía y su dominio del método histórico-artístico heredado de su maestro Gómez-Moreno, sobre cuya figura escribiría su discurso de ingreso en la Academia de la Historia. La publicación del epistolario de Ponz con el Conde del Aguila significa un testimonio más de su contribución a la erudición artística.

Fundó en Sevilla el Instituto Escuela y poseía el arte de enseñar. Su estilo didáctico y lleno de amenidad no pasó desapercibido a Eugenio D‘Ors quien, allá por los años veinte, le dedicó una de sus famosas glosas. Según Xenius, 
Juan de Mata Carriazo era de aquéllos que pueden «salir la pizarra». El origen del comentario orsiano se hallaba en la lectura del estudio sobre el sarcófago paleocristiano de Berja, el cual ofrecía más de lo que el título anunciaba, pues en un cuadro sinóptico excelente mostraba una ordenada clasificación de la primitiva escultura del arte cristiano en España en sus diferentes talleres. Era ésta una prueba magnífica de lo que el ensayista catalán denominaba inteligencia-dibujo. Pero había más, su prosa era de las que persiguen la forma clásica porque traslucía clara, exacta y precisa en las descripciones. Xenius afirmaba que por un cuadro sinóptico como aquél, era capaz de dar treinta y cinco de sus ensayos y por una descripción como la que Carriazo hacía del sarcófago de Berja, él daba al menos treinta y cinco páginas de Marcel Proust. 